Article

\title{
Imposed Water Deficit after Anthesis for the Improvement of Macronutrients, Quality, Phytochemicals, and Antioxidants in Rice Grain
}

\author{
Ramin Rayee ${ }^{1}$, Hoang-Dung Tran ${ }^{2}$, Tran Dang Xuan ${ }^{1, *}$ and Tran Dang Khanh ${ }^{3,4}$ \\ 1 Graduate School for International Development and Cooperation (IDEC), Hiroshima University, \\ Higashi-Hiroshima 739-8529, Japan; r.rayee12@yahoo.com \\ 2 Nguyen Tat Thanh University, Ho Chi Minh City 702000, Vietnam; thdung@ntt.edu.vn \\ 3 Agricultural Genetics Institute, Hanoi City 123000, Vietnam; tdkhanh@vaas.vn \\ 4 Vietnam National University of Agriculture, Hanoi City 131000, Vietnam \\ * Correspondence: tdxuan@hiroshima-u.ac.jp; Tel./Fax: +81-82-424-6927
}

Received: 17 November 2018; Accepted: 14 December 2018; Published: 18 December 2018

\begin{abstract}
The control of protein and amylose content is the principal challenge in rice nutrient and quality improvement. In this study, water deficits in 2- and 3-day intervals were imposed on two Japonica cultivars $\mathrm{K} 1$ and $\mathrm{K} 3$, and an Indica K4 subtype after anthesis to harvest. It was observed that although rice yield was affected, the protein content was increased $6.53-6.63 \%$ to 9.93-10.16\%. The amylose quantity was reduced significantly from $22.00-22.43 \%$ to $16.33-17.56 \%$, while fatty acids in rice grain were not influenced. Total anthocyanins were greatly promoted by $53.1 \%$ as compared to the non-treated trials. The antioxidant capacity in rice grain increased up to $59.1 \%$ in 2,2-diphenyl-1-picrylhydrazyl (DPPH) radical scavenging and $41.6 \%$ in reducing power assays. Findings of this research revealed that the 3-day interval of water deficit imposition was the most effective to improve rice macronutrients and quality, as well as beneficial phytochemicals and antioxidants in rice grain. The water control after anthesis to harvest in rice cultivation is beneficial and economical for farmers to improve rice nutrients and quality, thus contributes to the sustainable rice production in many developing countries.
\end{abstract}

Keywords: protein; amylose; water deficit stress; phytochemical; antioxidant activity; phenols; flavonoids; anthocyanins

\section{Introduction}

Global agriculture in the 21st century deals with the challenge of providing healthy and sufficient foods under increasing water deficit for the demand of rapid population growth [1-3]. Rice (Oryza sativa L.) is the staple food in Asia, where about $90 \%$ of the world's rice is produced and plays an important role to prepare food for a billion people in the world. It was reported that $80 \%$ percent of the total freshwater resources are used for rice irrigation in Asia [4], whilst rapid growing population with urban increasing and industrial evolution has made water scarce for irrigation [5].

The improvement of grain quality has been a crucial task in rice breeding worldwide [6]. Of which, the enhancement of protein content and fatty acids as macronutrients [7] and reduction of amylose content were among the most important goals. To date, marker-assisted breeding (MAS) has been the principal method to increase rice quality [8]. There were many quantitative trait locus (QTLs)/genes correlated to quality properties that have been mapped and cloned, associated with development of molecular markers to facilitate selection for specific types of grain quality [8]. The growth of the world population requires a doubling of rice production by 2050 [6]. The breeding of new rice cultivars 
with better nutrients and quality is complicated, laborious, and costly; thus, researchers in developing countries are facing a lack of facilities and funds as compared to developed countries. Therefore, the establishment of more effective, beneficial, and economical control to increase rice nutrients and quality is needed.

The response of rice to water deficit stress varied among species and genotypes, length, and severity of drought at molecular, cellular, and physiological levels [6]. Fofana et al. [9] observed that drought occurring at the ripening stage seems to promote the characters determining rice grain quality including total milling rate, head rice ratio, and protein content. Water deficit increased the remobilization of stored carbon accumulation and water-stress-accelerated grain-filling [10]. Meanwhile, the effect of water deficit on the rice quality may be different among upland and lowland rice varieties [11]. When plants are subjected to abiotic stresses, they accumulate phenolics, flavonoids, anthocyanin, and proline in greater quantity [12]. Some of these secondary metabolites are associated with cell walls, while others exist without any chemical bond within the plant cell vacuoles [13]. Whole rice grain contains phenolics and anthocyanin, which have been reported to reduce chronic diseases such as cancer, cardiovascular disease, and obesity [14]. The health benefits of anthocyanins are that they protect against oxidative damage, and promote the immune system and detoxification enzymes [15]. The principal role of proline is to preserve enzymes from dehydration and salt accumulation rather than to decrease osmotic potential in the plants [16]. On the other hand, the stimulation of plant antioxidant activity is an efficient defense mechanism against the effects of oxygen radicals [17]. It has been known that genotypic and environmental variables affect the phytochemicals and the bran color of rice grain [18].

Stress of water deficit at the anthesis stage has been known to reduce crop yield [19] for rice [20,21], corn (Zea mays L.) [22], oat (Avena sativa L.) [23], and barley (Hordeum vulgare L.) [24]. It was estimated that $50 \%$ of the rice production can be affected by drought [25]. Thus, there have been many studies conducted with attempts to breed rice cultivars tolerant to drought [26], as well as proper water use in rice production against drought [6]. In addition, a number of new rice varieties have been bred and released yearly with higher yield potential and stronger resistance to abiotic and biotic stresses. However, the grain nutrients and quality of such varieties is ignored [27]. It was proposed that cultivation technology should be improved to enhance crop water use efficacy and simultaneously preserve crop yield under drought stress to ensure food security in many developing countries [25]. The aim of this research was to examine the imposition of different water deficit intervals after anthesis to harvest on yield parameters, protein and fatty acids, amylose, and changes in phytochemicals and antioxidant potential in rice grain.

\section{Materials and Methods}

\subsection{Plant Materials and Treatments}

Seeds of three varieties including K1 and K3 (Japonica) and, K4 (Indica) were used. K1 and K3 were the two cultivars developed from the Koshihikari variety grown in Higashi Hiroshima, Hiroshima Prefecture, Japan. K1 was the Khang Dan, originated from North of Vietnam. First, the seeds were sterilized and immersed at $50{ }^{\circ} \mathrm{C}$ for $10 \mathrm{~min}$, then subsequently soaked at $25^{\circ} \mathrm{C}$ for $48 \mathrm{~h}$. The seeds were then washed many times with distilled water. The 20-day seedlings were transplanted in Wagner pots (height: $30 \mathrm{~cm}$; diameter: $20 \mathrm{~cm}$ ) which were filled with $4 \mathrm{~kg}$ commercial soil (JA-ZENCHU Co., Hiroshima, Japan) containing $0.16 \mathrm{~g}$ nitrogen $(\mathrm{N}), 0.2 \mathrm{~g}$ phosphorous $(\mathrm{P})$ and $0.26 \mathrm{~g}$ potassium $(\mathrm{K})$. The experiment was conducted based on the Randomized Complete Block Design (RCBD) with three replications. Each block (replication) consisted of six treatments (3 level of water and 3 varieties). Thus, totally the experiment had 81 pots. The maximum and minimum temperature in the greenhouse was 39 and $20^{\circ} \mathrm{C}$, respectively. Each pot was planted with three rice seedlings on 5 June 2017. After one week, they were thinned to two seedlings in each pot. $(\mathrm{N})$ was applied three times, including $0.5 \mathrm{~g} \mathrm{~N}$ in each 
pot one day before transplanting as basal fertilizer. $0.5 \mathrm{~g} \mathrm{~N}$ as top dressing at 30 days after transplanting (DAT) and $0.2 \mathrm{~g}$ at 65 DAT. $2.0 \mathrm{~g}(\mathrm{P})$ and $2 \mathrm{~g}(\mathrm{~K})$ were applied one day before transplanting.

Rice plants were irrigated to maintain $85 \%$ soil moisture until anthesis. The $85 \%$ soil moisture was monitored using the moisture meter TDR-341F (Fujiwara Scientific Company Co., Ltd., Osaka, Japan). Three days after anthesis, different trials of continuous flooding which the water level was maintained $5 \mathrm{~cm}$ above the soil as control (W1), intermittent flooding at 2-day intervals (W2) followed by two days no irrigation and intermittent flooding at 3-day intervals (W3) followed by three days no irrigation were applied until harvest. At harvest, the plant spikes were dried at $50{ }^{\circ} \mathrm{C}$ for $48-72 \mathrm{~h}$. Rice grains were separated and adjusted to $14 \%$ moisture content using oven method before further analysis.

\subsection{Rice Yield}

Filled grain number per panicle, filled grain percentage, and weight of 100 seeds were measured as grain yield components. Subsequently, rice grains were dehulled using an automatic rice husker machine (model TR-250, Kett Electric Laboratory, Tokyo, Japan) to remove the rice husk. The non-polished grains were evaluated for protein, amylose, and fatty acid contents, which were measured using a quality tester machine (PGC Shizuoka Seiki PS-500) version (2-12, Shizuoka Seiki Co., Ltd., Shizuoka, Japan).

\subsection{Chemicals}

Folin-Ciocalteu reagent, sodium hydroxide, DPPH (1,1-diphenyl-2-picrylhydrazyl), BHT (dibutyl hydroxytoluene), aluminum (III) chloride hexahydrate $\left(\mathrm{AlCl}_{3} \cdot 6 \mathrm{H}_{2} \mathrm{O}\right)$, sodium carbonate $\left(\mathrm{Na}_{2} \mathrm{CO}_{3}\right)$, and other chemicals were purchased from Kanto Chemical Co., Inc., Tokyo, Japan.

\subsection{Free Phenolics}

Total free phenolics was extracted following the method described by Shao et al. [14] with slight modifications. An amount of $1.0 \mathrm{~g}$ of rice flour extracted with $20 \mathrm{~mL}$ of $90 \%$ methanol twice. The mixture was shaken at room temperature for $40 \mathrm{~min}$, then centrifuged (HITACHI, CF15RXII, Tokyo, Japan) at $15,300 \times g$ for $10 \mathrm{~min}$ at $4{ }^{\circ} \mathrm{C}$ to collect the supernatants. The obtained solvent was evaporated using a rotary evaporator (SB-350-EYELA, Tokyo, Japan) at $37{ }^{\circ} \mathrm{C}$ to remove methanol after adjusting the $\mathrm{pH}$ to 1.5-2.0. The precipitates were defatted using hexane three times then extracted with $60 \mathrm{~mL}$ of ethyl acetate three times. It was then evaporated to dryness using a rotary evaporator, and finally dissolved in $50 \%$ methanol for further analysis.

\subsection{Bound Phenolics}

The residue after extracting the free phenolics was washed by $40 \mathrm{~mL}$ of distilled water. Briefly, an amount of $1.5 \mathrm{~g}$ of the residue was hydrolyzed using $50 \mathrm{~mL}$ of $4 \mathrm{M} \mathrm{NaOH}$ and stirred for $4 \mathrm{~h}$ at $50{ }^{\circ} \mathrm{C}$. The mixture was then centrifuged (HITACHI, CF15RXII, Tokyo, Japan) for $30 \mathrm{~min}$ to remove the residue trash after adjusting the $\mathrm{pH}$ to $1.5-2.0$ using $37 \%$ hydrochloric acid. The extract was defatted using hexane and extracted with ethyl acetate. After dryness, the precipitate was dissolved in $50 \%$ methanol for further analysis.

\subsection{Total Phenolic Content (TPC)}

The TPC was measured following the Folin-Ciocalteu method as described by Ti et al. [28] with slight modifications. A fractional $0.125 \mathrm{~mL}$ of the extracts was added in $0.5 \mathrm{~mL}$ of distilled water and $0.125 \mathrm{~mL}$ of Foline-Cioacalteu reagent, and then neutralized with $1.25 \mathrm{~mL}$ of $7 \%$ sodium carbonate. The mixture was incubated for $90 \mathrm{~min}$ at room temperature in the dark. The absorbance was read at $760 \mathrm{~nm}$ using a microplate reader (Thermo Fisher Scientific Oy - Ratastie 2, 01620 Vantaa - Finland). The total phenolic content is shown as mg gallic acid equivalent (mg GAE)/100 $\mathrm{g}$ dry weight (DW). 


\subsection{Total Flavonoid Content (TFC)}

The TFC was calculated following the colorimetric method as described by Ti et al. [28]. An amount of $0.5 \mathrm{~mL}$ of the extract was mixed with $0.5 \mathrm{~mL}$ of $2 \%$ aluminum chloride solution. The absorbance was read at $510 \mathrm{~nm}$ using a microplate reader (Thermo Fisher Scientific Oy - Ratastie 2, 01620 Vantaa - Finland). The TFC was expressed as mg rutin equivalent (RE)/100 g DW.

\subsection{Antioxidant Activities}

\subsubsection{DPPH Radical Scavenging Activity}

The free radical scavenging activity was performed following the method as described by Elzaawely et al. [29]. A volume of $0.5 \mathrm{~mL}$ extract from rice grain was mixed with $0.25 \mathrm{~mL}$ of DPPH solution and $0.1 \mathrm{~mL}$ of $0.1 \mathrm{M}$ acetate buffer $\mathrm{pH}$ (5.5). The mixture was shaken and kept at room temperature for $30 \mathrm{~min}$ in the dark. The absorbance was measured at $517 \mathrm{~nm}$ using a microplate reader (Thermo Fisher Scientific Oy - Ratastie 2, 01620 Vantaa - Finland). The BHT standard (5-20 ppm) was used as the positive reference. The inhibition concentration $\left(\mathrm{IC}_{50}\right)$ was the concentration of the samples, which give a 50\% DPPH radical scavenging activity. Thus, the lower $\mathrm{IC}_{50}$ value indicated the higher antioxidant activity. The following formula calculated the percentage of DPPH radical scavenging activity:

$$
\text { DPPH Radical Scavengin Activity }(\%)=[(\text { Acontrol }- \text { Asample })] \times 100
$$

In the formula, Acontrol shows the absorbance of the reaction without a sample. Asample indicates the absorbance of the sample.

\subsubsection{Reducing Power}

The reducing power was determined using the method as described by Singh et al. [30]. Briefly, an aliquot of $0.1 \mathrm{~mL}$ of the extract was added with $2.5 \mathrm{~mL}$ potassium ferricyanide $(1 \%)$ and $2.5 \mathrm{~mL}$ of phosphate buffer $\left(0.2 \mathrm{M}, \mathrm{pH}\right.$ 6.5). The mixture was incubated at $50{ }^{\circ} \mathrm{C}$ for $30 \mathrm{~min}$. Then, $2.5 \mathrm{~mL}$ of trichloroacetic acid $(10 \%)$ was added to the mixture. The mixture was centrifuged at $4000 \mathrm{rpm}$ for $10 \mathrm{~min}$, and an aliquot of $2.5 \mathrm{~mL}$ of the supernatant was subsequently taken and mixed with $2.5 \mathrm{~mL}$ of distilled water and $0.5 \mathrm{~mL} \mathrm{FeCl}_{3}(0.1 \%)$. The absorbance was read at $700 \mathrm{~nm}$ using a microplate reader (Thermo Fisher Scientific Oy - Ratastie 2, 01620 Vantaa - Finland). The BHT standard (5-20 ppm) was used as the positive control. The $\mathrm{IC}_{50}$ value was calculated, thus a lower $\mathrm{IC}_{50}$ indicated a higher antioxidant activity.

\subsection{Total Anthocyanin Content (TAC)}

The TAC was measured following the method reported by Fuleki et al. [31]. Of which, an amount of $0.5 \mathrm{~g}$ rice flour was extracted with $15 \mathrm{~mL}$ methanol: $1 \mathrm{M} \mathrm{HCl}(85: 15, v / v)$ three times using a stirrer in the dark. The mixture was centrifuged at $4100 \mathrm{~g}$ for $15 \mathrm{~min}$ at room temperature. Two buffers were prepared: the first one at $\mathrm{pH} 1.0(1.49 \% \mathrm{KCl}$ water buffer, acidified with hydrochloric acid) and the second buffer at $\mathrm{pH} 4.5$ (1.64\% sodium acetate water buffer acidified with hydrochloric acid). After diluting the samples 10 times and getting a volume of $2 \mathrm{~mL}$, the absorbance of each sample was read at $520 \mathrm{~nm}$ and $700 \mathrm{~nm}$ using a microplate reader (Thermo Fisher Scientific Oy - Ratastie 2, 01620 Vantaa - Finland). The formula below was used to calculate TAC, whilst the TAC was shown as a cyaniding-3-glucoside equivalent:

$$
\text { Total anthocyanin }\left(\frac{m g}{l}\right)=A \times M W \times D F \times \frac{1000}{(€ \times \mathrm{L})}
$$

where $A$ was the absorbance, which was calculated to be: $A=(\mathrm{A} 520 \mathrm{~nm}-\mathrm{A} 700 \mathrm{~nm}) \mathrm{pH} 1.0-$ $(\mathrm{A} 520 \mathrm{~nm}-\mathrm{A} 700 \mathrm{~nm}) \mathrm{pH}$ 4.5. MW was the molecular weight for cyanidin-3-glucoside $(449.2 \mathrm{~g} / \mathrm{mole})$, 
$D F$ is the dilute factor, and $€$ was the molar absorbance of cyanidin-3-glucoside $(26,900 \mathrm{~L} /(\mathrm{cm}$ mole), $\mathrm{L}$ was cell path length $(1 \mathrm{~cm})$, and 1000 was the conversion factor from $\mathrm{mL}$ to liter.

\subsection{Proline Content}

The proline content was determined following the method as described by Bates et al. [32]. An amount of $0.5 \mathrm{~g}$ of rice flour was homogenized with $10 \mathrm{~mL}$ of sulfosalicylic acid $(3 \%)$. The homogenate was centrifuged at $3000 \mathrm{rpm}$ for $10 \mathrm{~min}$. Then, an aliquot of $2 \mathrm{~mL}$ of the supernatant was mixed with $2 \mathrm{~mL}$ acid ninhydrin and $2 \mathrm{~mL}$ of glacial acetic acid in a test tube and kept in the water bath at $100{ }^{\circ} \mathrm{C}$ for $95 \mathrm{~min}$, and the reaction was finalized in an ice bath. The mixture was extracted with $4 \mathrm{~mL}$ toluene, and the absorbance was measured at $520 \mathrm{~nm}$ using toluene as the blank. Pure proline (20-100 ppm) was used as a standard. The proline accumulation was calculated as below:

$$
\text { Proline } \frac{\mu \text { moles }}{g} D W:\left[\frac{\left(\text { proline } \frac{\mu \mathrm{g}}{\mathrm{ml}} \times \text { mltoluene }\right)}{115.5 \frac{\mu \mathrm{g}}{\mu \mathrm{mole}}}\right] \div\left[\frac{\text { g sample }}{5}\right]
$$

\subsection{Statistical Analysis}

The data were analyzed using Minitab 16.0 (Minitab Inc., State College, PA, USA). Results were reported as means + standard deviation (SD). Differences among varieties and treatments were found using ANOVA (analysis of variance), followed by Tukey multiple comparison tests. The level of significance was $5 \%(p<0.05)$.

\section{Results}

\subsection{Grain Yield Components}

The influence of water treatments apparently affected yield components (Table 1). The filled grains were not affected due to the W2 and W3 treatments, whilst the influence on filled grain, weight of 100 seeds, and grain weight per pot varied among yield parameters and treatments, of which W3 showed the highest reduction. Comparing between the subtypes Japonica K1 and K2 and Indica K3, no marked difference was observed (Table 1).

Table 1. Grain yield components responded to water deficit stress.

\begin{tabular}{|c|c|c|c|c|c|}
\hline Variety & Treatments & $\begin{array}{c}\text { Filled Grain } \\
\text { (Number/Panicle) }\end{array}$ & $\begin{array}{l}\text { Filled Grain } \\
(\%)\end{array}$ & $\begin{array}{l}\text { Weight of } \\
\text { 100-Seeds (g) }\end{array}$ & $\begin{array}{l}\text { Grain Weight } \\
\text { per Pot }(\mathrm{g})\end{array}$ \\
\hline \multirow{3}{*}{ K1 } & W1 & $146.0^{\mathrm{a}}$ & $98.0^{a}$ & $2.1^{a}$ & $56.8^{a}$ \\
\hline & W2 & $143.0^{\mathrm{a}}$ & $92.7^{\mathrm{ab}}$ & $1.8^{\mathrm{b}}$ & $54.8^{\mathrm{a}}$ \\
\hline & W3 & $130.0^{\mathrm{a}}$ & $87.5^{\mathrm{b}}$ & $1.7^{\mathrm{b}}$ & $33.9^{b}$ \\
\hline \multirow{3}{*}{$\mathrm{K} 2$} & W1 & $130.0^{a}$ & $98.4^{a}$ & $2.6^{\mathrm{a}}$ & $50.3^{a}$ \\
\hline & W2 & $127.0^{\mathrm{a}}$ & $91.8^{a b}$ & $2.5^{\mathrm{a}}$ & $48.8^{a}$ \\
\hline & W3 & $118.0^{\mathrm{a}}$ & $84.4^{\mathrm{b}}$ & $2.4^{\mathrm{b}}$ & $40.3^{b}$ \\
\hline \multirow{3}{*}{$\mathrm{K} 3$} & W1 & $199.0^{\mathrm{a}}$ & $98.1^{a}$ & $1.9^{\mathrm{a}}$ & $95.0^{a}$ \\
\hline & W2 & $210.0^{a}$ & $86.9^{b}$ & $1.8^{\mathrm{ab}}$ & $64.5^{b}$ \\
\hline & W3 & $206.0^{a}$ & $80.4^{b}$ & $1.7^{\mathrm{b}}$ & $45.3^{b}$ \\
\hline \multicolumn{6}{|l|}{ ANOVA } \\
\hline Variety & & * & * & * & * \\
\hline Treatment & & NS & * & * & * \\
\hline
\end{tabular}

W1: Continuous flooding (control), W2: 2-day interval, W3 = 3-day interval. Means with similar letters within a column are not significantly different at the $5 \%$ level. ${ }^{*}$ indicates significant differences at $(p<0.05)$; NS indicates non-significant. 


\subsection{Grain Macronutrients and Quality}

Table 2 shows the contents of protein and fatty acids (macronutrients) and quality (amylose) rice grain. In general, the interruption of water provision increased the protein content more than the control, of which W3 showed a greater protein content value than W2 (Table 2). In contrast, the amylose percentage was declined significantly at 2- and 3-day intervals, of which the W3 treatment caused greater reduction of amylose content. The influence on amylose content varied among rice cultivars (Table 2). In case of fatty acids, the irrigation intervals did not show any significant influence among treatments and rice varieties (Table 2). The discontinuous provision of water at 2- or 3-day intervals increased protein content, but in contrast, the amylose content was markedly decreased, whist fatty acids in rice grains were not affected. In general, only protein and amylose were affected by the imposition of a water deficit (Table 2). To compare between the two subtypes Indica and Japonica, no significance in protein was observed, whereas the amylose content of the Indica K4 was less affected than the Japonica K1 and K2 (Table 2).

Table 2. Grain quality contents responded to water deficit stress.

\begin{tabular}{|c|c|c|c|c|}
\hline Variety & Treatments & Protein $\%$ & Amylose\% & Fatty Acid\% \\
\hline \multirow{3}{*}{$\mathrm{K} 1$} & W1 & $6.83 \pm 0.78^{b}$ & $22.43 \pm 0.44^{\mathrm{a}}$ & $7.67 \pm 3.18^{a}$ \\
\hline & W2 & $8.63 \pm 0.80^{a b}$ & $19.14 \pm 0.57^{b}$ & $5.00 \pm 0.58^{a}$ \\
\hline & W3 & $9.70 \pm 0.28^{a}$ & $17.56 \pm 0.60^{b}$ & $9.67 \pm 2.73^{a}$ \\
\hline \multirow{3}{*}{ K3 } & W1 & $6.53 \pm 0.46^{b}$ & $22.30 \pm 1.00^{\mathrm{a}}$ & $8.33 \pm 3.84^{a}$ \\
\hline & W2 & $8.30 \pm 0.60^{a b}$ & $19.10 \pm 1.10^{\mathrm{ab}}$ & $9.00 \pm 0.57^{\mathrm{a}}$ \\
\hline & W3 & $10.16 \pm 0.60^{a}$ & $16.33 \pm 0.88^{b}$ & $10.00 \pm 1.00^{\mathrm{a}}$ \\
\hline \multirow{3}{*}{ K4 } & W1 & $6.63 \pm 0.68^{b}$ & $22.00 \pm 0.72^{a}$ & $4.33 \pm 0.88^{a}$ \\
\hline & W2 & $9.46 \pm 0.48^{a}$ & $21.50 \pm 1.50^{a}$ & $4.00 \pm 0.00^{a}$ \\
\hline & W3 & $9.93 \pm 0.60^{\mathrm{a}}$ & $18.20 \pm 1.10^{\mathrm{a}}$ & $3.66 \pm 0.33^{a}$ \\
\hline \multicolumn{5}{|l|}{ ANOVA } \\
\hline Variety & & NS & NS & * \\
\hline Treatment & & * & * & NS \\
\hline
\end{tabular}

W1 = Continuous flooding (control), W2 = 2-day interval, W3 = 3-day interval. Means with similar letters within a column are not significantly different at the $5 \%$ level. ${ }^{*}$ indicates significant differences at $(p<0.05)$; NS indicates non-significant.

\subsection{Total Anthocyanin (TAC) and Proline Contents}

It was observed that the water deficit markedly increased total anthocyanin contents, of which the W3 treatment obtained a higher TAC value than the W2. It was suggested that the duration of water deficit associated with the increase of total anthocyanins. Similarly, the proline contents promoted when water was interrupted at W2 interval. The amount of proline was significantly increased at W3 interval in greater level than the W2 (Table 3). It was proposed that both anthocyanins and prolines induced by rice plants in water deficit stress. The drought duration was proportional to the increase of anthocyanins and prolines in rice (Table 3).

Table 3. Effect of water deficit stress on total anthocyanin (TAC) and proline content.

\begin{tabular}{cccc}
\hline Variety & Treatments & $\begin{array}{c}\text { TAC (mg Cyanidin-3-Glucoside } \\
\text { Equivalent/100 g DW) }\end{array}$ & $\begin{array}{c}\text { Proline Content } \\
(\boldsymbol{\mu m o l e s} / \mathbf{g} \text { DW) }\end{array}$ \\
\hline \multirow{2}{*}{ K1 } & W1 & $20.27 \pm 0.80^{\mathrm{c}}$ & $4.10 \pm 1.50^{\mathrm{b}}$ \\
& W2 & $25.30 \pm 2.40^{\mathrm{b}}$ & $5.30 \pm 2.60^{\mathrm{b}}$ \\
& W3 & $36.00 \pm 0.70^{\mathrm{a}}$ & $6.40 \pm 1.90^{\mathrm{a}}$ \\
\hline
\end{tabular}


Table 3. Cont.

\begin{tabular}{|c|c|c|c|}
\hline Variety & Treatments & $\begin{array}{c}\text { TAC (mg Cyanidin-3-Glucoside } \\
\text { Equivalent/100 g DW) }\end{array}$ & $\begin{array}{l}\text { Proline Content } \\
(\mu \mathrm{moles} / g \mathrm{DW})\end{array}$ \\
\hline \multirow{3}{*}{ K3 } & W1 & $16.40 \pm 2.60^{c}$ & $3.30 \pm 0.80^{b}$ \\
\hline & W2 & $28.80 \pm 2.40^{\mathrm{ab}}$ & $4.00 \pm 0.70^{a}$ \\
\hline & W3 & $35.00 \pm 1.60^{b}$ & $4.30 \pm 0.50^{\mathrm{a}}$ \\
\hline \multirow{3}{*}{ K4 } & W1 & $20.93 \pm 2.20^{b}$ & $2.10 \pm 0.10^{b}$ \\
\hline & W2 & $26.40 \pm 0.70^{b}$ & $3.00 \pm 0.20^{b}$ \\
\hline & W3 & $35.50 \pm 3.50^{\mathrm{a}}$ & $3.40 \pm 0.60^{\mathrm{a}}$ \\
\hline \multicolumn{4}{|l|}{ ANOVA } \\
\hline Variety & & NS & * \\
\hline Treatment & & * & * \\
\hline
\end{tabular}

\subsection{Total Phenolic (TPC) and Total Flavonoid Contents (TFC)}

Table 4 showed that total flavonoids were increased in W2 and W3 treatments as compared to the control W1; however, no statistically significant difference was observed among treatments. Similarly, no marked difference among treatments against free phenolics was found. In contrast, the bound phenolics were promoted, of which W3 induced greater amounts of bound phenolics than W2 and the control W1 (Table 4).

Table 4. Phenolic and flavonoid responses to water deficit stress in rice grain.

\begin{tabular}{|c|c|c|c|c|c|}
\hline \multirow{2}{*}{ Variety } & \multirow{2}{*}{ Treatments } & \multicolumn{2}{|c|}{ Phenolics (mg GAE/100 g DW) } & \multicolumn{2}{|c|}{ Flavonoids (mg RE/100 g DW) } \\
\hline & & Free & Bound & Free & Bound \\
\hline \multirow{3}{*}{$\mathrm{K} 1$} & W1 & $21.26 \pm 3.60^{a}$ & $21.10 \pm 2.80^{b}$ & $10.55 \pm 0.44^{\mathrm{a}}$ & $12.22 \pm 1.61^{a}$ \\
\hline & W2 & $26.26 \pm 3.20^{\mathrm{a}}$ & $23.93 \pm 9.70^{b}$ & $9.55 \pm 0.44^{\mathrm{a}}$ & $11.39 \pm 1.17^{\mathrm{a}}$ \\
\hline & W3 & $33.43 \pm 5.50^{\mathrm{a}}$ & $39.80 \pm 19.60^{\mathrm{a}}$ & $10.22 \pm 10^{a}$ & $20.06 \pm 4.97^{\mathrm{a}}$ \\
\hline \multirow{3}{*}{ K3 } & W1 & $23.10 \pm 1.80^{\mathrm{a}}$ & $13.40 \pm 0.50^{\mathrm{b}}$ & $8.88 \pm 0.16^{\mathrm{a}}$ & $12.72 \pm 2.78^{a}$ \\
\hline & W2 & $21.43 \pm 1.50^{\mathrm{a}}$ & $43.90 \pm 11.10^{\mathrm{a}}$ & $9.55 \pm 0.6^{\mathrm{a}}$ & $17.89 \pm 3.49^{\mathrm{a}}$ \\
\hline & W3 & $25.26 \pm 5.20^{\mathrm{a}}$ & $48.90 \pm 17.80^{\mathrm{a}}$ & $9.05 \pm 0.44^{\mathrm{a}}$ & $17.22 \pm 5.25^{\mathrm{a}}$ \\
\hline \multirow{3}{*}{ K4 } & W1 & $23.43 \pm 4.60^{\mathrm{a}}$ & $16.26 \pm 3.40^{\mathrm{b}}$ & $9.05 \pm 0.83^{\mathrm{a}}$ & $10.55 \pm 0.72^{\mathrm{a}}$ \\
\hline & W2 & $22.93 \pm 1.80^{\mathrm{a}}$ & $35.26 \pm 4.80^{\mathrm{ab}}$ & $9.72 \pm 0^{\mathrm{a}}$ & $12.39 \pm 1.42^{\mathrm{a}}$ \\
\hline & W3 & $29.43 \pm 2.20^{a}$ & $50.9 \pm 10.90^{\mathrm{a}}$ & $10 \pm 00.167^{\mathrm{a}}$ & $16.22 \pm 1.61^{\mathrm{a}}$ \\
\hline \multicolumn{6}{|l|}{ ANOVA } \\
\hline Variety & & NS & NS & NS & NS \\
\hline Treatment & & NS & * & NS & NS \\
\hline
\end{tabular}

W1 = Continuous flooding (control), W2 = 2-day interval, W3 = 3-day interval. Means with similar letters within a column are not significantly different at the $5 \%$ level. ${ }^{*}$ indicates significant differences at $(p<0.05)$ and NS indicates non-significant. DW: dry weight.

\subsection{Antioxidant Activity}

In Table 5, the DPPH radical scavenging and reducing power activities were expressed using the $\mathrm{IC}_{50}$ values, thus the lower $\mathrm{IC}_{50}$ indicated greater antioxidant activity. It was found that compared to the control, both DPPH scavenging and reducing power activities were significantly higher than the controls, of which the W3 treatment showed markedly greater levels of DPPH radical scavenging activity than the W2. The reducing power was promoted, but the W2 treatment was not significantly different from the control. The W3 treatment caused greater reducing power than the W2 and the controls (Table 5). 
Table 5. DPPH radical scavenging and reducing power activities.

\begin{tabular}{|c|c|c|c|}
\hline \multirow{2}{*}{ Variety } & \multirow{2}{*}{ Treatments } & DPPH & Reducing Power \\
\hline & & $\left(\mathrm{IC}_{50} \mathrm{mg} / \mathrm{mL}\right)$ & $\left(\mathrm{IC}_{50} \mathrm{mg} / \mathrm{mL}\right)$ \\
\hline \multirow{3}{*}{$\mathrm{K} 1$} & W1 & $9.06 \pm 8.40^{a}$ & $12.8 \pm 2.36^{\mathrm{a}}$ \\
\hline & W2 & $5.56 \pm 2.90^{b}$ & $9.53 \pm 2.62^{a b}$ \\
\hline & W3 & $3.71 \pm 0.40^{b}$ & $7.47 \pm 0.37^{b}$ \\
\hline \multirow{3}{*}{$\mathrm{K} 3$} & W1 & $13.27 \pm 11.70^{\mathrm{a}}$ & $17.73 \pm 3.02^{\mathrm{a}}$ \\
\hline & W2 & $9.75 \pm 5.90^{\mathrm{ab}}$ & $15.86 \pm 3.86^{\mathrm{a}}$ \\
\hline & W3 & $6.00 \pm 1.30^{b}$ & $9.55 \pm 0.62^{b}$ \\
\hline \multirow{3}{*}{ K4 } & W1 & $11.36 \pm 40^{\mathrm{a}}$ & $18.40 \pm 2.95^{\mathrm{a}}$ \\
\hline & W2 & $9.46 \pm 3.50^{b}$ & $15.60 \pm 2.33^{a}$ \\
\hline & W3 & $8.16 \pm 1.60^{b}$ & $13.95 \pm 0.98^{b}$ \\
\hline \multicolumn{3}{|c|}{ ANOVA } & \\
\hline Variety & & * & * \\
\hline Treatment & & * & * \\
\hline
\end{tabular}

W1 = Continues flooding (control), W2 = 2-day interval, W3 = 3-day interval. Means with similar letters within a column are not significantly different at the $5 \%$ level. ${ }^{*}$ indicates significant differences at $(p<0.05)$.

\subsection{Correlation among Quality Traits, Phytochemical Contents, and Antioxidant Activity}

The correlations among the quality contents, phytochemical capacity, and antioxidant activity are shown in Table 6 . The result indicated that protein $\%$ had a significantly negative correlation with amylose $\%(r=-0.84, p=0.01)$, whilst it revealed a significantly positive correlation with TPC $(r=0.88$, $p=0.01), \mathrm{RP} \%(r=0.88, p=0.01)$, and TAC $(r=0.92, p=0.001)$. The TPC expressed a significantly positive correlation with TFC $(r=0.78, p=0.05)$ and TAC $(r=0.93, p=0.001)$, and exerted more RP\% $(r=0.83, p=0.01)$ rather than DPPH $\%$. From the antioxidant activity assays, a positive significant correlation was observed between RP\% and TAC $(r=0.86, p=0.01)$.

Table 6. Correlation among quality traits, phytochemical contents, and antioxidant activity.

\begin{tabular}{|c|c|c|c|c|c|c|c|c|c|}
\hline & Protein $\%$ & Amylose\% & $\begin{array}{c}\text { Fatty } \\
\text { Acid } \%\end{array}$ & TPC & TFC & DPPH\% & $\mathrm{RP} \%$ & PC & TAC \\
\hline Protein \% & 1 & & & & & & & & \\
\hline Amylose \% & $-0.84^{* *}$ & 1 & & & & & & & \\
\hline Fatty acid $\%$ & 0.04 & -0.36 & 1 & & & & & & \\
\hline TPC & $0.88^{* *}$ & $-0.82^{* *}$ & 0.17 & 1 & & & & & \\
\hline TFC & 0.64 & -0.78 & 0.62 & $0.78 *$ & 1 & & & & \\
\hline DPPH \% & 0.39 & -0.31 & -0.20 & 0.56 & 0.25 & 1 & & & \\
\hline $\mathrm{RP} \%$ & $0.88^{* *}$ & $-0.87^{* *}$ & 0.20 & $0.83^{* *}$ & 0.68 * & 0.23 & 1 & & \\
\hline PC & 0.43 & -0.60 & 0.53 & 0.28 & 0.58 & -0.51 & 0.57 & 1 & \\
\hline TAC & $0.92^{* * *}$ & $\underset{* * *}{-0.91}$ & 0.18 & $0.93^{* * *}$ & $0.81^{* *}$ & 0.37 & $0.86^{* *}$ & 0.49 & 1 \\
\hline
\end{tabular}

$*, * *, * * *$ indicates significant correlation at the $0.05,0.01$, and 0.001 levels, respectively: TPC, total phenolic content: TFC, total flavonoid content; RP, reducing power: PC, proline content: TAC, total anthocyanin content.

\section{Discussion}

Roughly $34 \%$ of rice is cultivated in rainfed lowland, $9 \%$ in rainfed upland, and $9 \%$ in flood-prone area, while irrigated ecosystem accounts for $50 \%$ total world rice cultivation area [33]. Water deficit is the principal catalyst of many famines and caused destructive effects on rice production worldwide. Asia is the most affected region, with total losses of crop and livestock reached $\$ 28$ billion, followed by Africa with $\$ 25$ billion [34]. Drought devastates rice at panicle initiation and flowering [35]. However, this study showed that, in contrast, the implication of a water deficit after anthesis was effective on rice macronutrients, yield, phytochemicals, and antioxidant activities. The imposition of water deficit 
after anthesis to harvest in rice cultivation as conducted by this study can be implemented easily by farmers in many developing countries.

In this study, the filled grain number per panicle did not change in W2 and W3 treatments, whereas the filled grains percentage, weight of 100 -seeds, and grain weight per pot slightly decreased in W2 and W3 (Table 1). It was reported that intermittent irrigations increased the number of unfilled grain [36] and the water-stress-enhanced grain-filling period to result in a reduction of grain weight [10]. In intermittent irrigation, the oxygen supply was improved, and this condition helped rice to uptake more nutrients. In this study, the protein percentage was increased significantly by both W2 and W3 treatments. Simultaneously, the amylose content was markedly reduced, meanwhile no change on fatty acids in rice grain was found (Table 2). The impact of water deficit stress on rice grain quality was different for upland and low land cultivars $[37,38]$. The increase of rice protein as a macronutrient can be beneficial to people in many places in the world [39], although the high protein content may decrease the eating quality and viscogram capacity [40]. Therefore, the imposition of water deficit during grain filling and ripening stage may be a useful factor on improving rice quality.

Anthocyanins are water soluble pigments that are linked with sugars, such as glucose, galactose, etc., and can be found in glycosylated forms [41]. Anthocyanins, as health-enhancing substances, have been found in many cereal grains, of which black rice showed the highest TAC [42]. In rice, TAC in rice grain was generally lower than in leaves and roots [43]. However, via the treatment of water deficit after anthesis until harvest by this study, TAC was significantly promoted in rice grain (Table 3). The induced accumulation of proline in the rice plant was related to an increase of proline antecedents such as glutamic acid, ornithine, and arginine [44]. The endosperm of small cereals contained proline, which contributed to the protein storage and the aroma of the rice grain [45]. This research found that the proline quantity in rice grain was more pronounced in water deficit treatments, as this finding was consistent with previous studies [46]. Although total flavonoids were not influenced, the amount of bound phenolics was strongly increased (Table 4) and it might be associated with the acceleration of antioxidant activities in rice grain (Table 5). Nichols et al. [47] demonstrated that phenolic compounds, such as quercetin and kaempferol glycosides, had some protective functions primarily as antioxidants, which could be increased by herbivore discouragement and sunscreen against UV destruction.

DPPH is the spectrophotometric procedure that is commonly used to determine the antioxidant properties of the sample extracts. Plants synthesized various bioactive compounds to respond to biotic and abiotic stresses [48]. Grain as the principal product of the rice plant and the source of nutritional elements plays a significant role in defending the body from oxidative damages. In this study's rice grain, antioxidants tended to increase significantly for W2 and W3 (Table 5). It was reported that the rice grain antioxidant activity was associated with phenolic, proline, and anthocyanin content [49]. Thus, it was shown that the antioxidant activity in rice was promoted by the increase of these phytochemicals in rice grains by imposing a water deficit after anthesis in this study.

In this study, by imposition of water deficit at 3-day intervals after anthesis, a significant positive correlation was revealed among protein content, TPC, RP\%, and total anthocyanin content, whilst a significantly negative correlation was observed with amylose percentage (Table 6). Based on the findings of this study, TPC and TFC contributed to higher antioxidant activity (RP\%) and TAC, which make these results consistent with previous studies [50].

\section{Conclusions}

Findings of this research highlighted that the treatment of water deficit at 3-day intervals after anthesis showed a more effective influence on rice yield and quality parameters, phytochemicals (total phenolics and total anthocyanins), and antioxidant activity than the 2-day interval. Although filled grain, weight of 100 seeds, and grain weight per pot were slightly reduced, contents of protein, amylose, and fatty acid were significantly increased. Total anthocyanins and proline were markedly promoted, but total phenolics and flavonoids were not influenced much. The antioxidant capacity including DPPH radical scavenging and reducing power activities were significantly accelerated. 
This study indicated that imposition of water deficit at 3-day intervals increased nutrients and health benefits in rice grain. The control of water provision as implemented in this study is apparently beneficial for farmers to produce better nutrients and quality rice grain in a sustainable and economical rice production in many developing countries.

Author Contributions: R.R. and T.D.X. conceived and implemented the experiments, analyzed data and wrote the manuscripts. T.D.K., T.H.D., and T.D.X. gave advice and revised the manuscript. All authors agreed with the final version of the manuscript.

Funding: This research is partly supported by Nguyen Tat Thanh University, Vietnam.

Acknowledgments: The authors thank Japan International Cooperation Agency (JICA) for giving Ramin Rayee a scholarship. Pham Thi Thu Ha, Truong Ngoc Minh, Yusuf Andriana, and Ismael Haqani are appreciated for their assistance to this research. Thanks also for the partial support by the Foundation of Science and Technology Development at Nguyen Tat Thanh University.

Conflicts of Interest: The authors declare no conflict of interests.

\section{References}

1. Bouman, B.A.M. A conceptual framework for the improvement of crop water productivity at different spatial scales. Agric. Syst. 2007, 93, 43-60. [CrossRef]

2. Linquist, B.A.; Anders, M.M.; Adviento-Borbe, M.A.A.; Chaney, R.L.; Nalley, L.L.; Da Rosa, E.F.; van Kessel, C. Reducing greenhouse gas emissions, water use, and grain arsenic levels in rice systems. Glob. Chang. Biol. 2015, 21, 407-417. [CrossRef] [PubMed]

3. Linquist, B.; van Groenigen, K.J; Adviento-Borbe, M.A.; Pittelkow, C.; van Kessel, C. An agronomic assessment of greenhouse gas emissions from major cereal crops. Glob. Chang. Biol. 2012, 18, 194-209. [CrossRef]

4. Bouman, B.A.M.; Tuong, T.P. Field water management to save water and increase its productivity in irrigated lowland rice. Agric. Water Manag. 2001, 49, 11-30. [CrossRef]

5. Belder, P.; Spiertz, J.H.J;; Bouman, B.A.M.; Lu, G.; Tuong, T.P. Nitrogen economy and water productivity of lowland rice under water-saving irrigation. Field Crops Res. 2005, 93, 169-185. [CrossRef]

6. Zain, N.A.M.; Ismail, M.R.; Puteh, A.; Mahmood, M.; Islam, M.R. Impact of cyclic water stress on growth, physiological responses and yield of rice (Oryza sativa L.) grown in tropical environment. Cienc. Rural 2014, 44, 2136-2141. [CrossRef]

7. Kitta, K.; Ebihara, M.; Iizuka, T.; Yoshikawa, R.; Isshiki, K.; Kawamoto, S. Variations in lipid content and fatty acid composition of major non-glutinous rice cultivars in Japan. J. Food Compos. Anal. 2005, 18, 269-278. [CrossRef]

8. Spindel, J.; Begum, H.; Akdemir, D.; Virk, P.; Collard, B.; Redona, E.; McCouch, S.R. Genomic selection and association mapping in rice (Oryza sativa L.): Effect of trait genetic architecture, training population composition, marker number and statistical model on accuracy of rice genomic selection in elite, tropical rice breeding lines. PLoS Genet. 2015, 11, e1004982.

9. Fofana, M.; Cherif, M.; Kone, B.; Futakuchi, K.; Audebert, A. Effect of water deficit at grain repining stage on rice grain quality. J. Agric. Biotechnol. Sustain. Dev. 2010, 2, 100-107.

10. Pandey, A.; Kumar, A.; Pandey, D.S.; Thongbam, P.D. Rice quality under water stress. Indian J. Adv. Plant Res. 2014, 1, 23-26.

11. Cheng, W.; Zhang, G.; Zhao, G.; Yao, H.; Xu, H. Variation in rice quality of different cultivars and grain positions as affected by water management. Field Crops Res. 2003, 80, 245-252. [CrossRef]

12. Hayat, S.; Hayat, Q.; Alyemeni, M.N.; Wani, A.S.; Pichtel, J.; Ahmad, A. Role of proline under changing environments: A review. Plant Signal. Behav. 2012, 7, 1456-1466. [CrossRef] [PubMed]

13. Pourali, O.; Asghari, F.S.; Yoshida, H. Production of phenolic compounds from rice bran biomass under subcritical water conditions. Chem. Eng. J. 2010, 160, 259-266. [CrossRef]

14. Shao, Y.; Xu, F.; Sun, X.; Bao, J.; Beta, T. Phenolic acids, anthocyanins, and antioxidant capacity in rice (Oryza sativa L.) grains at four stages of development after flowering. Food Chem. 2014, 143, 90-96. [CrossRef] [PubMed]

15. Hosseinian, F.S.; Li, W.; Beta, T. Measurement of anthocyanins and other phytochemicals in purple wheat. Food Chem. 2008, 109, 916-924. [CrossRef] [PubMed] 
16. Thomas, H. Accumulation and consumption of solutes in swards of Lolium perenne during drought and after rewatering. New Phytol. 1991, 118, 35-48. [CrossRef]

17. Sherwin, H.W.; Farrant, J.M. Protection mechanisms against excess light in the resurrection plants Craterostigma wilmsii and Xerophyta viscosa. Plant Growth Regul. 1998, 24, 203-210. [CrossRef]

18. Goffman, F.D.; Bergman, C.J. Rice kernel phenolic content and its relationship with antiradical efficiency. J. Sci. Food Agric. 2004, 84, 1235-1240. [CrossRef]

19. Mia, S.; Liu, H.; Wang, X.; Lu, Z.; Yan, G. Rresponse of wheat to post-anthesis water stress, and the nature of gene action as revealed by combining ability analysis. Crop Pasture Sci. 2017, 68, 534-543. [CrossRef]

20. Ekanayake, I.J.; de Datta, S.K.; Steponkus, P.L. Spikelet sterility and flowering response of rice to water stress at anthesis. Ann. Bot. 1989, 63, 257-264. [CrossRef]

21. Wu, N.; Guan, Y.; Shi, Y. Effect of water stress on physiological traits and yield in rice backcross lines after anthesis. Energy Procedia 2011, 5, 255-260. [CrossRef]

22. Robins, J.S.; Domingo, C.E. Some effects of severe soil moisture deficits at specific growth stages of corn. Agron. J. 1953, 45, 612-621. [CrossRef]

23. Shandhu, B.S.; Horton, M.L. Response of oats to water deficit. I. Physiological characteristics. Agron. J. 1977, 69, 357-360.

24. Aspinall, D.; Nicholls, P.B.; May, L.H. The effects of soil moisture stress on the growth of barley. 1. Vegetative development and grain yield. Aust. J. Agric. Res. 1964, 15, 729-745. [CrossRef]

25. Gauthami, P.; Subrahmanyam, D.; Padma, V.; Rao, P.R.; Voleti, S.R. Influence of simulated post-anthesis water stress on stem dry matter remobilization, yield and its component in rice. Ind. J. Plant Physiol. 2013, 18, 177-182. [CrossRef]

26. Quan, N.T.; Anh, L.H.; Khang, D.T.; Tuyen, P.T.; Toan, N.P.; Minh, T.N.; Minh, L.T.; Bach, D.T.; Ha, P.T.T.; Elzaawely, A.A.; et al. Involvement of secondary metabolites in response to drought stress of rice (Oryza sativa L.). Agriculture 2016, 6, 23. [CrossRef]

27. Pang, Y.; Ali, J.; Wang, X.; Franje, N.J.; Revilleza, J.E.; Xu, J.; Li, Z. Relationship of rice grain amylose, gelatinization temperature and pasting properties for breeding better eating and cooking quality of rice varieties. PLoS ONE 2016, 11, e0168483. [CrossRef] [PubMed]

28. Ti, H.; Zhang, R.; Zhang, M.; Li, Q.; Wei, Z.; Zhang, Y.; Ma, Y. Dynamic changes in the free and bound phenolic compounds and antioxidant activity of brown rice at different germination stages. Food Chem. 2014, 161, 337-344. [CrossRef] [PubMed]

29. Elzaawely, A.A.; Xuan, T.D.; Tawata, S. Essential oils, kava pyrones and phenolic compounds from leaves and rhizomes of Alpinia zerumbet (Pers.) B.L. Burtt. \& R.M. Sm. and their antioxidant activity. Food Chem. 2007, 103, 486-494.

30. Singh, R.; Kumari, N. Comparative determination of phytochemicals and antioxidant activity from leaf and fruit of Sapindus mukorrossi Gaertn. A valuable medicinal tree. Ind. Crops Prod. 2015, 73, 1-8. [CrossRef]

31. Fuleki, T.; Francis, F.J. Quantitative methods for anthocyanins and degradation of total juice anthocyanin index for Cranberry. J. Food Sci. 1968, 33, 78-83. [CrossRef]

32. Bates, L.S.; Waldren, R.P.; Teare, I.D. Rapid determination of free proline for water-stress studies. Plant Soil 1973, 39, 205-207. [CrossRef]

33. Sandhu, N.; Kumar, A. Bridging the rice yield gaps under drought: QTLs, genets, and their use in breeding program. Agronomy 2017, 2, 27. [CrossRef]

34. Food Agriculture Organization. The Impact of Natural Hazards and Disasters on Agriculture and Food and Nutrition Security: A Call for Action to Build Resilient Livelihoods; FAO: Rome, Italy, 2015.

35. Sabetfar, S.; Ashouri, M.; Amiri, E.; Babazadeh, S. Effect of drought stress at differeng growth stages on yield and yield component of rice plant. Persian Gulf Crop Prot. 2013, 2, 14-18.

36. Sepaskhah, A.R.; Yousofi-Falakdehi, A. Interaction between the effects of deficit irrigation and water salinity on yield and yield components of rice in pot experiment. Plant Prod. Sci. 2009, 12, 168-175. [CrossRef]

37. Renmin, W.; Yuanshu, D. Studies on ecological factors of rice from heading to maturity. I. Effect of different soil moisture content on fertilization, grain-filling and grain quality of early Indica rice. J. Zhejiang Univ. Sci. 1989, 2, 011.

38. Dingkuhn, M.; LeGal, P.Y. Effect of drainage date on yield and dry matter partitioning in irrigated rice. Field Crops Res. 1996, 46, 117-126. [CrossRef] 
39. Ishima, T. Effect of nitrogenous fertilizer application and protein content in milled rice on organoleptic quality of cooked rice. Rep. Natl. Food Res. Inst. 1974, 29, 9-15.

40. Shen, P.; Luo, Q.X.; Jin, Z.X. Relationship between protein content and the cooking and eating quality propreties of rice grain. J. Northeast Agric. Univ. 2003, 34, 368-371.

41. Shipp, J. Food applications and physiological effects of anthocyanins as functional food ingredients. Open Food Sci. J. 2010, 4, 7-22. [CrossRef]

42. Abdel-Aal, E.S.; Young, M.J.C.; Rabalski, I. Anthocyanin composition in black, blue, pink, purple, and red cereal grains. J. Agric. Food Chem. 2006, 54, 4696-4704. [CrossRef] [PubMed]

43. Sutharut, J.; Sudarat, J. Total anthocyanin content and antioxidant activity of germinated colored rice. Int. Food Res. J. 2012, 19, 215-221.

44. Ashraf, M.F.M.R.; Foolad, M. Roles of glycine betaine and proline in improving plant abiotic stress resistance. Environ. Exp. Bot. 2007, 59, 206-216. [CrossRef]

45. Kavi Kishor, P.B.; Sreenivasulu, N. Is proline accumulation per se correlated with stress tolerance or is proline homeostasis a more critical issue? Plant Cell Environ. 2014, 37, 300-311. [CrossRef] [PubMed]

46. Ren, Y.; Ashraf, U.; He, L.X.; Mo, Z.W.; Wang, F.; Wan, X.C.; Tang, X.R. Irrigation and nitrogen management practices affect grain yield and 2-acetyl-1-pyrroline content in aromatic rice. Appl. Ecol. Environ. Res. 2017, 15, 1447-1460. [CrossRef]

47. Nichols, S.N.; Hofmann, R.W.; Williams, W.M. Physiological drought resistance and accumulation of leaf phenolics in white clover interspecific hybrids. Environ. Exp. Bot. 2015, 119, 40-47. [CrossRef]

48. Callaway, R.M.; Vivanco, J.M. Can plant biochemistry contribute to understanding of invasion ecology? Trends Plant Sci. 2006, 11, 574-580.

49. Sumczynski, D.; Kotásková, E.; Družbíková, H.; Mlček, J. Determination of contents and antioxidant activity of free and bound phenolics compounds and in vitro digestibility of commercial black and red rice (Oryza sativa L.) varieties. Food Chem. 2016, 211, 339-346. [CrossRef] [PubMed]

50. Li, X.; Wu, X.; Huang, L. Correlation bewteen antioxidant activities and phenolic contents of Radix Angelicae Sinesis (Danggui). Molecules 2009, 14, 5349-5361. [CrossRef] [PubMed]

(C) 2018 by the authors. Licensee MDPI, Basel, Switzerland. This article is an open access article distributed under the terms and conditions of the Creative Commons Attribution (CC BY) license (http://creativecommons.org/licenses/by/4.0/). 